Eur. J. Clin. Chem. Clin. Biochem.

Vol. 30, 1992, pp. 275-279

(C) 1992 Walter de Gruyter \& Co. Berlin $\cdot$ New York

\title{
The Extent of Diffuse Intravascular Coagulation and Fibrinolysis in Patients with Liver Cirrhosis
}

\author{
By J.W.J.van Wersch ${ }^{1}, M . G . V . M$. Russel $^{2}$ and F.A.Th. Lustermans ${ }^{2}$ )
}

\author{
1 Haematological Laboratory \\ 2 Department of Internal Medicine
}

De Wever Ziekenhuis, Heerlen, The Netherlands

(Received October 1, 1991/February 20, 1992)

\begin{abstract}
Summary: Twenty-five patients with different stages of liver cirrhosis were evaluated with regard to the degree of liver synthesis reduction, the extent of the decrease of blood coagulation factors and/or alterations of the fibrinolytic system. For the assessment of the residual level of liver synthesis we used pseudo-cholinesterase and serum albumin as references. We did not find a correlation between these quantities and antithrombin III or fibrinogen, but highly significant inverse correlations with tissue plaminogen activator activity and Ddimer concentration. We found considerable alterations in the concentrations of the coagulation and fibrinolysis factors, with the exception of fibrinogen and plasminogen activator inhibitor. Significant increases were seen for thrombin-antithrombin III complex, tissue plasminogen activator activity and D-dimer, while significant decreases were seen for antithrombin III and $\alpha_{2}$-antiplasmin, compared with a group of healthy volunteers. In the group of patients with liver cirrhosis and reduced liver synthesis, as documented by lowered pseudo-cholinesterase and serum albumin, the reduction of both antithrombin III and $\alpha_{2}$-antiplasmin was most prominent. Intravascular coagulation was negligibly small. For the fibrinolytic system, the increase of tissue plasminogen activator, the decrease of the fibrinolysis inhibitor $\left(\alpha_{2}\right.$-antiplasmin $)$ and the elevated $D$ dimer concentration seem to be important. These results suggest an acceleration of fibrinolysis and the prolonged presence of cross-linked fibrin degradation products.
\end{abstract}

\section{Introduction}

The liver plays a central role in the mechanisms of blood coagulation and fibrinolysis. It is well known that patients with chronic liver disease may have severe coagulopathies. Most blood coagulation and profibrinolytic proteins, like antithrombin III, plasminogen and $\alpha_{2}$-antiplasmin are synthesized in the liver. Impairment of the liver function has repercussions on the synthesis of these and other proteins (1).

Besides the reduction of coagulation and fibrinolysis factors, the synthesis of other proteins is also decreased. In this respect, pseudo-cholinesterase (EC 3.1.1.8) and serum albumin are known to be reliable indicators of the reduced protein synthesis by the liver. There has been much debate as to whether and to what extent, in addition to synthesis reduction, the consumption of blood coagulation factors plays a role in liver cirrhosis $(2,3)$. The impaired synthesis of the coagulation factors and the possible presence of diffuse intravascular coagulation hamper the correct asessement of the fibrinolytic activity. But liver cirrhosis is probably the most common clinical condition in which an increase of products of endogenous fibrinolytic activity can be measured $(4,5)$.

The aim of this study was to estimate the extent of the decrease of antithrombin III, due to decreased liver synthesis, and the proportion of this decrease caused by enhanced consumption. Activation of the clotting pathway was determined by measurement of the thrombin-antithrombin III complex. Fibrinogen was determined as an additional measure of possible consumptive coagulation. 
In addition, we assessed the fibrinolysis regulating constituents, $\alpha_{2}$-antiplasmin, tissue plasminogen activator and plasminogen activator inhibitor-1, as well as the fibrinolysis-derived D-dimers, in order to assess the coagulation/fibrinolysis balance.

The relevant part of the coagulation and fibrinolysis cascade is given in figure 1.

\section{Materials and Methods}

\section{Patients selection}

Twenty-five patients ( 18 males and 7 females aged from 38 to 82 years) at different stages of hepatic failure were studied. Patients were considered to have cirrhosis if they showed either biopsy evidence of cirrhosis or documented portal hypertension (presence of oesophagus varices or redistribution of tracer to spleen and bone marrow on liver-spleen scanning) in the setting of clear-cut parenchymal liver disease and appropriate historical background (heavy alcohol abuse or viral hepatitis).

Most patients had alcoholic liver disease, while the remainder had either post-viral cirrhosis or cirrhosis of unknown origin The severity of liver disease was estimated using the ChildTurcotte classification (6). Seven patients had mild cirrhosis
(Child A), eleven had moderate cirrhosis (Child B) and seven had advanced cirrhosis (Child $\mathrm{C}$ ). Exclusion criteria were a coexistent malignancy, thromboembolic process or medication known to have influence on the coagulation system.

The control group consisted of fifty subjectively healthy volunteers.

\section{Methods}

The pseudo-cholinesterase activity was measured in serum (reference range $2800-9000 \mathrm{U} / \mathrm{l}$ ) with butyrylthiocholine iodide as substrate according to the manufacturer's instructions (Boehringer Mannheim, Germany).

Fibrinogen was determined according to Clauss on a Schnittger and Gross coagulometer, with reagents from Hoffmann-La Roche. The chromogenic substrate assay for antithrombin III was from Kabi Vitrum. Thrombin-antithrombin III was determined with an Elisa kit from the Behring Corporation (Marburg, Germany).

D-Dimer was assayed in plasma with an Elisa method (Boehringer Mannheim Corp., Mannheim, Germany). For the determination of plasminogen activator inhibitor-1, the test kit of Kabi Vitrum Diagnostica (Mölndal, Sweden) Coa-set PAI was used. The $\alpha_{2}$-antiplasmin and tissue-plasminogen activator activity tests were also from Kabi Vitrum Diagnostica.

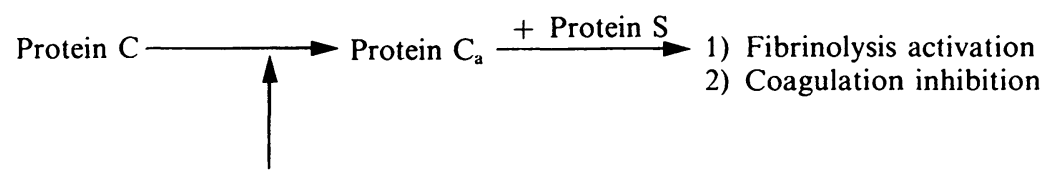

Endothelium surface-thrombomodulin-thrombin

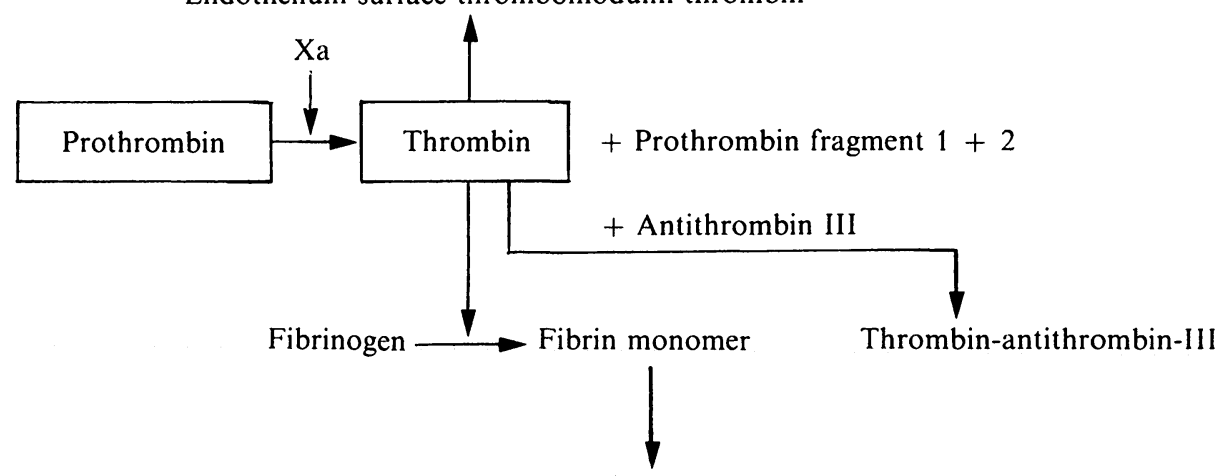

Fibrin polymer

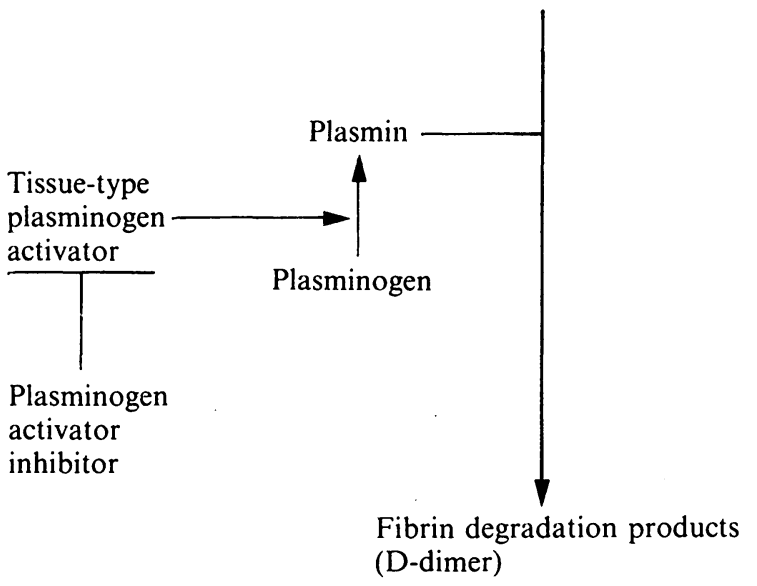

Fig. 1. Relevant part of the coagulation and fibrinolysis cascade 


\section{Samples}

Blood for the plasma determinations was collected by venipuncture with sodium citrate as anticoagulant (final concentration $11 \mathrm{mmol} / \mathrm{l})$. Plasma was prepared by centrifugation at $1800 \mathrm{~g}$ for $30 \mathrm{~min}$. The plasma was stored at $-70{ }^{\circ} \mathrm{C}$ in plastic tubes and thawed with tap water for $5 \mathrm{~min}$ before serial analysis.

For the measurement of tissue plasminogen activator activity, $1 \mathrm{ml}$ of citrate blood was added to a separate tube containing $0.5 \mathrm{ml}$ acetate buffer $(\mathrm{pH}=3.9)$. The tube was centrifuged immediately $(30 \mathrm{~min}, 1800 \mathrm{~g})$ and the plasma separated. The collected plasma was acidified with $20 \%$ acetic acid (final pH of the plasma sample $4.0-4.1$ ). This plasma was stored at $-70{ }^{\circ} \mathrm{C}$ in plastic tubes and thawed with tap water for $5 \mathrm{~min}$ before analysis.

For the serum determinations the venous blood was collected in plain plastic vials (Sarstedt, Nümbrecht, Germany). The blood was allowed to clot at room temperature for $60 \mathrm{~min}$, then centrifuged in the collection tube $(15 \mathrm{~min}, 3000 \mathrm{~g})$. The serum was stored at $-70^{\circ} \mathrm{C}$ until analysis.

\section{Statistical analysis}

For statistical analysis, the Mann-Whitney-Wilcoxon and Spearman rank correlation tests were used, and a p-value of $<0.05$ was considered to be significant. All values were expressed as mean $\pm \mathrm{SD}$.

\section{Results}

We did not find a significant correlation between pseudo-cholinesterase and antithrombin III ( $r=0.2241 ; p=0.2722$ ) or between serum albumin and antithrombin III ( $\mathrm{r}=0.3050, \mathrm{p}=0.1357)$. However a significant correlation between pseudo-cholinesterase and serum albumin existed $(r=0.6888$, $\mathrm{p}=0.007$ ). For pseudo-cholinesterase and serum albumin, highly significant inverse correlations were found with $\mathrm{D}$-dimer and tissue plasminogen activator activity (tab. 1).

Comparison of the patient group with a reference group with respect to coagulation and fibrinolysis factors is summarized in table 2 . With the exception

Tab. 1. Relevant Spearman rank correlations between pseudocholinesterase and serum albumin on one hand and antithrombin III, D-dimer and tissue plasminogen activator on the other hand.

\begin{tabular}{|c|c|c|}
\hline Spearman rank correlation between: & $r$ & p-value \\
\hline $\begin{array}{l}\text { Antithrombin-III and pseudo-cholin- } \\
\text { esterase }\end{array}$ & 0.2241 & 0.2722 \\
\hline Antithrombin-III and serum albumin & 0.3050 & 0.1357 \\
\hline $\begin{array}{l}\text { Pseudo-cholinesterase and serum al- } \\
\text { bumin }\end{array}$ & 0.6888 & 0.0007 \\
\hline $\begin{array}{l}\text { D-dimer and pseudo-cholinesterase } \\
\text { D-dimer and serum albumin }\end{array}$ & $\begin{array}{l}-0.6373 \\
-0.6255\end{array}$ & $\begin{array}{l}0.0035 \\
0.0041\end{array}$ \\
\hline $\begin{array}{l}\text { Tissue plasminogen activator and } \\
\text { pseudo-cholinesterase }\end{array}$ & -0.4360 & 0.0327 \\
\hline $\begin{array}{l}\text { Tissue plasminogen activator and } \\
\text { serum albumin }\end{array}$ & -0.4970 & 0.0149 \\
\hline
\end{tabular}

Tab. 2. Comparison of the patient group and the reference group: the percentages of values exceeding the upper or lower limit of the reference ranges are given. The differences of the mean values were tested with the Mann-Whitney-Wilcoxon test.

\begin{tabular}{|c|c|c|c|c|c|c|c|}
\hline \multirow[t]{2}{*}{ Blood constituents } & \multicolumn{2}{|c|}{$\begin{array}{l}\text { Reference group } \\
(\mathrm{n}=50)\end{array}$} & \multicolumn{2}{|c|}{$\begin{array}{l}\text { Patient group } \\
(\mathrm{n}=25)\end{array}$} & \multirow{2}{*}{$\begin{array}{l}\text { Decreased } \\
\text { values } \\
\%\end{array}$} & \multirow{2}{*}{$\begin{array}{l}\text { Raised } \\
\text { values } \\
\%\end{array}$} & \multirow{2}{*}{$\begin{array}{l}\text { Signifi- } \\
\text { cancy } \\
\text { p-value }\end{array}$} \\
\hline & mean & SD & mean & SD & & & \\
\hline $\begin{array}{l}\text { Fibrinogen } \\
(\mathrm{g} / \mathrm{l})\end{array}$ & 2.9 & 0.6 & 3.2 & 3.4 & 0 & 44 & n.s. \\
\hline $\begin{array}{l}\text { Antithrombin III* } \\
(\%)\end{array}$ & 98.4 & 12.2 & 61.0 & 15.9 & 85 & 0 & $<0.0001$ \\
\hline $\begin{array}{l}\text { Thrombin-antithrombin III* } \\
(\mu \mathrm{g} / \mathrm{l})\end{array}$ & 2.5 & 0.9 & 5.1 & 3.5 & 4 & 48 & $<0.001$ \\
\hline $\begin{array}{l}\text { D-dimer* } \\
(\mu \mathrm{g} / \mathrm{l})\end{array}$ & 238 & 100 & 2492 & 2713 & 0 & 72 & $<0.0001$ \\
\hline $\begin{array}{l}\alpha_{2} \text {-antiplasmin* } \\
\quad(\%)\end{array}$ & 98.0 & 11.0 & 64.9 & 17.8 & 76 & 0 & $<0.0001$ \\
\hline $\begin{array}{l}\text { Tissue plasminogen activator* } \\
\left(\times 10^{3} \mathrm{IU} / \mathrm{l}\right)\end{array}$ & 1.6 & 0.5 & 4.0 & 2.9 & 13 & 73 & $<0.02$ \\
\hline $\begin{array}{l}\text { Plasminogen activator inhibitor-1 } \\
\left(\times 10^{3} \mathrm{AU} / \mathrm{l}\right)\end{array}$ & 2.2 & 1.2 & 1.8 & 2.0 & 0 & 9 & n.s. \\
\hline $\begin{array}{l}\text { Pseudo-cholinesterase* } \\
\text { (IU/l) }\end{array}$ & 5900 & 1500 & 3148 & 1750 & 42.9 & 0 & $<0.0001$ \\
\hline$\underset{(\mathrm{g} / \mathrm{l})}{\text { Albumin* }}$ & 42.5 & 3.8 & 30.0 & 10.0 & 65.2 & 0 & $<0.0001$ \\
\hline
\end{tabular}


of fibrinogen and plasminogen activator inhibitor-1, we found significant differences between the mean values of the patient and the reference group for all other quantities. The mean of antithrombin-III was reduced from $98.4 \%(=300 \mathrm{mg} / \mathrm{l})$ to $61.6 \%(=186$ $\mathrm{mg} / \mathrm{l}$ ), for pseudo-cholinesterase from $5900 \mathrm{U} / \mathrm{l}$ (mean value of the reference group) to $3148 \mathrm{U} / 1$ and for serum albumin from 42.5 to $30.0 \mathrm{~g} / \mathrm{l}$. With regard to the fibrinolysis quantities we found a significant decrease of $\alpha_{2}$-antiplasmin from $98 \%$ to $64.9 \%$, a significant increase for D-dimer (from 238 to $2482 \mathrm{mg} /$ ) and tissue plasminogen activator activity (from 1.6 to $\left.4.0 \cdot 10^{3} \mathrm{AU} / \mathrm{l}\right)$.

\section{Discussion}

In the present study, some specific coagulation factors (antithrombin III, thrombin-antithrombin III complex, fibrinogen) and a number of factors of the fibrinolytic system $\left(\alpha_{2}\right.$-antiplasmin, tissue plasminogen activator activity, plasminogen activator inhibitor-1 and D-dimer) were determined in the blood of liver cirrhosis patients. Correlations were sought between the changes in the concentrations of these factors and the extent of decreased liver synthesis, as indicated by the catalytic concentration of pseudocholinesterase and the concentration of serum albumin. The activity of pseudo-cholinesterase was decreased to $53.4 \%$ of the mean reference pool serum activity, whereas serum albumin decreased by $29.5 \%$. The antithrombin III level decreased from $98.5 \%$ to $61.0 \%$ (a reduction of $37.5 \%$ ). Although these figures are in concordance with each other, we only could demonstrate a significant correlation between pseudocholinesterase and serum albumin $(r=0.6888$; $\mathrm{p}=0.0007$ ), with no significant correlation between antithrombin III and pseudo-cholinesterase or serum albumin. This implies either a separate location for the antithrombin III synthesis in the liver, or, as often stated in liver cirrhosis, an enhanced consumption of antithrombin III. Several authors $(7,8)$ have studied this factor of intravascular clotting activation by measuring fibrinopeptide $\mathrm{A}$. The results were however conflicting and gave no clear evidence for blood coagulation consumption. The results of this study however almost exclude diffuse intravascular coagulation, because the antithrombin III level reduction of $37.5 \%$ equals a reduction of approximately $112.5 \mathrm{mg} / \mathrm{l}$, whereas the coagulation marker, thrombin-antithrombin III complex, showed only a limited increase (from 2.5 in the reference group to $5.1 \mathrm{~g} / 1$ in the patient group). Thus, coagulation activation is present but the proportion seems to be negligible. This view is supported by the unaltered fibrinogen level in these patients.

With regard to fibrinolysis, we found an enhanced tissue plasminogen activator activity in the cirrhosis group in comparison with a reference group of healthy volunteers, which is in agreement with earlier studies on this topic $(9,10)$. Furthermore we found unchanged levels of plasminogen activator inhibitor-1 activity and increased concentrations of fibrin degradation products ( $\mathrm{D}$-dimers). This raises the question of whether hyperfibrinolysis can really be assumed when fibrin degradation products are enhanced, but there is no substantial evidence for coagulation activation, as in the present study. The explanation might be that the synthesis of $\alpha_{2}$-antiplasmin is reduced (10) and the clearance of tissue plasminogen activator in patients with liver cirrhosis is diminished $(11,12)$. Reduction of the excretion of tissue plasminogen activator leads to enhanced levels of tissue plasminogen activator; this in turn stimulates the generation of plasmin, which is inadequately inhibited by the decreased $\alpha_{2}$-antiplasmin. The resulting effect might be a continuous production of crosslinked fibrin degradation products (D-dimers), which leads, in combination with a reduced clearance, to enhanced D-dimer levels. Indeed, enhanced tissue plasminogen activator activity levels, strongly elevated $\mathrm{D}$-dimer levels and decreased $\alpha_{2}$-antiplasmin concentrations have been found in this study. Moreover, plasma urokinase-type plasminogen activator may be elevated in some subjects with liver cirrhosis (13), and this also contributes to an enhancement of fibrinolysis.

Recently Leebeek et al. (14) showed that the ratios of tissue plasminogen activator antigen and plasminogen activator inhibitor-1 antigen were increased in most patients with liver cirrhosis. They discuss the possibility that it may be caused by a selective increase in tissue plasminogen activator synthesis or by a selective change in the clearance, by the diseased liver, of tissue plasminogen activator versus plasminogen activator inhibitor-1. The overall effect is a shift of the balance between tissue plasminogen activator and plasminogen activator inhibitor-1.

In summary our results show that the antithrombin III reduction is much more prominent than the thrombin-antithrombin III complex elevation. Thus, only a minor proportion of antithrombin III reduction appears to be due to consumption. The level of tissue plasminogen activator is sufficient to activate plasminogen to plasmin, which is not adequately inhibited 
by $\alpha_{2}$-antiplasmin and therefore leads to enhanced fibrinolysis (D-dimers). The relatively high $\mathrm{D}$-dimer concentrations present in the plasma of cirrhosis patients are probably due to impaired clearance by the liver. In this manner, a kind of hyperfibrinolysis is mimicked, which can interfere with the coagulation process and cause or aggravate bleeding complications in patients with cirrhosis of the liver (15).

\section{References}

1. Cordova, C., Violi, F., Alessandri, C., Ferro, D., Saliola, M., Musca, A. \& Balsano, F. (1986) Prekallikrein and factor VII as prognostic indexes of liver failure. Am. J. Clin. Pathol. 85, 579-582.

2. Mariongu, F., Mameli, G., Acca, M. R., Mamusa, A. M., Mulas, G. \& Balestrieri, A. (1988) Low grade DIC in liver cirrhosis: fact or fiction? Thromb. Haemost. 59, 344.

3. Mombelli, G., Monotti, R., Haeberli, A. \& Straub, P. W. (1988) Low grade DIC in liver cirrhosis: fact or fiction? Rebuttal. Thromb. Haemost. 59, 344.

4. Francis, R. B. (1989) Clinical disorders of fibrinolysis. A critical review. Blut $59,1-14$.

5. Violi, F., Ferro, D., Saliola, M., Quintarelli, C. \& Alessandri, C. (1989) Evaluation of D-Dimer in patients with liver cirrhosis. Thromb. Haemost. 62, 1149-1150.

6. Child III, C. G. \& Turcotte, G. (1964) Surgery and portal hypertension. In: The liver and portal hypertension (Child III, C. G., ed.) p. 50, Philadelphia: WB Saunders.

7. Coccheri, S., Mannucci, P. M., Palareti, G., Gervasoni, W., Poggi, M. \& Vigano, S. (1982) Significance of plasma fibrinopeptide $\mathrm{A}$ and high molecular weight fibrinogen in patients with liver cirrhosis. Br. J. Haematol. 52, 503-509.

8. Mombelli, G., Monotti, R., Haeberli, A. \& Straub, P. W. (1987) Relationship between fibrinopeptide A and fibrinogen/fibrin fragment $\mathrm{E}$ in thromboembolism, DIC and various non-thromboembolic diseases. Thromb. Haemost. 58, $758-763$.

9. Hersch, S., Kunelis, T. \& Francis, R. B. Jr. (1987) Pathogenesis of accelerated fibrinolysis in liver cirrhosis: a critical role for tissue plasminogen activator inhibitor. Blood 69 , 1315-1319.

10. Knot, E. A. R., Drijfhout, H. R., Ten Cate, J. W., De Jong, E., Iburg, A. H. C., Kahlé, L. H. \& Grijm, R. (1985) $\alpha_{2-}$ Plasmin inhibitor mechanism in patients with liver cirrhosis. J. Lab. Clin. Med. 105, 353-358.

11. Nilsson, T., Wallen, P. \& Mellbring, G. (1984) In vivo metabolism of human tissue-type plasminogen activator. Scand. J. Haematol. 33, 49-53.

12. Hersch, S., Kunelis, T. \& Francis, R. B. Jr. (1987) Pathogenesis of accelerated fibrinolysis in liver cirrhosis: a critical role for tissue plasminogen activator. Blood 69, 13151319.

13. Booth, N. A., Anderson, J. A. \& Bennet, B. (1984) Plasminogen activators in alcoholic cirrhosis: demonstration of increased tissue type and urokinase type activator. J. Clin Pathol. 37, 772-777.

14. Leebeek, F. W. G., Kluft, C., Knot, E. A. R., de Maat, M. P. M. \& Wilson, J. H. P. (1991) A shift in balance between profibrinolytic and antifibrinolytic factors causes enhanced fibrinolysis in liver cirrhosis: role of tissue-type plasminogen activator, plasminogen activator and $\alpha_{2}$-antiplasmin. Gastroenterology $101,1382-1390$.

15. Francis, R. B. Jr. \& Feinstein, D. I. (1984) Clinical significance of accelerated fibrinolysis in liver disease. Haemostasis $14,460-465$

Dr. J. W. J. van Wersch

De Wever Hospital

PO Box 4446

NL-6401 CX Heerlen 
